IRSTI 47.29.31

\title{
On the efficiency of cooled solar panels
}

\author{
${ }^{1}$ Paunkov N., ${ }^{2 *}$ Popov R., ${ }^{3}$ Nedelcheva S. and ${ }^{4}$ Georgiev A. \\ ${ }^{I}$ Faculty of Electronics and Automation, Technical University of Sofia, Plovdiv Branch, Bulgaria \\ ${ }^{2}$ Plovdiv university Paisii Hilendarski, Plovdiv, Bulgaria \\ ${ }^{3}$ Faculty of Engineering and Pedagogy - Sliven, Technical University of Sofia, Bulgaria \\ ${ }^{4}$ Faculty of Mechanical Engineering, Technical University of Sofia, Plovdiv Branch, Bulgaria \\ *e-mail: rum_pop@yahoo.com
}

\begin{abstract}
The photovoltaic (PV) solar panels are getting bigger applications in the practice. Their efficiency is better at lower temperatures. Normally the panels are cooled with the ambient air (in this case the gained heat is dissipated to the surrounding without any application). A successful combination of photovoltaic solar panel and solar collector is the so called photovoltaic-thermal (PV/T) solar panel. There are some significant advantages of the PV/T panels - aesthetic advantage over the PV panels, usage in places where the area is limited, reduction of the installation costs and architectural unity between roof and PV/T panels. The article analyses two solar panels - the PV solar panel of the type polycrystalline silicon (pc$\mathrm{Si}$ ) and the PV/T Solar Module CPVT60P250 (both solar panels are produced by the Crane Company using silicone cells from EKS - Solaris $\mathrm{GmbH}$ ). Some tests are implemented and a comparison between the efficiencies of both panels is done.
\end{abstract}

Key words: combined photovoltaic/thermal (PV/T) solar panel, photovoltaic solar panel, natural experiments, improved panel efficiency.

PACS numbers: 96.60.-j 72.40.+w, 72.80.Cw, 84.60.Jt

\section{Introduction}

Solar photovoltaic-thermal panels (or $\mathrm{PV} / \mathrm{T}$ panels) are a combination of photovoltaic cells and a solar thermal collector, i.e. they are a facility that turns solar radiation into electricity and heat at the same time [1]. As a result, PV-T panels generate more energy per unit area than a combination from individual PV (photovoltaic) panels and solar thermal collectors [2]. Thus, they present a new technology where the produced heat is some times more than the electricity [3].

There are some categorizations of the $\mathrm{PV} / \mathrm{T}$ panels. The first one is after the fluid used in the panel (gas or liquid). The solar PV/T air panels are not so much used in the summer time because of the limited necessity of heat [4]. The liquid PV/T panels have good applications mainly in the lowtemperature range (starting by 10 to $80^{\circ} \mathrm{C}$ ). They are used in different building installation as a coolant in evaporator circuits of "water to water" heat pumps $\left(0\right.$ to $10^{\circ} \mathrm{C}$ ), in installation for heating of the pools $\left(25\right.$ to $35^{\circ} \mathrm{C}$ ) and for production of domestic hot water and heating of buildings (not more than $60{ }^{\circ} \mathrm{C}$ ) [5]. On the other side the liquid PV/T panels can be divide in two different panel types depending on the upper glass cover [6]. The glass-covered $\mathrm{PV} / \mathrm{T}$ panels have higher electrical efficiency compared to the glazed panels. On the other side the glazed panels possess bigger thermal efficiency than the efficiency of the glass-covered PV/T panels. There is normally done a value's combination of the average thermal and electrical efficiency.

Simultaneous optimization of electrical and thermal efficiencies was done, too. It is presented by Mohsen in [7] - an experimental study and simulation of a solar photovoltaic thermal (PV/T) air collector was implemented. The results show (Figure 1) that electrical efficiency increase with 2.5 $\%$ at relative constant thermal efficiency (for example about 51.5\%). Something similar happens with the thermal efficiency - it can be higher with about $2.5 \%$ at relative constant thermal efficiency (for example about 9.3\%). This concept was developed by Vilfredo Pareto and is used as effectively from the engineering designers. 


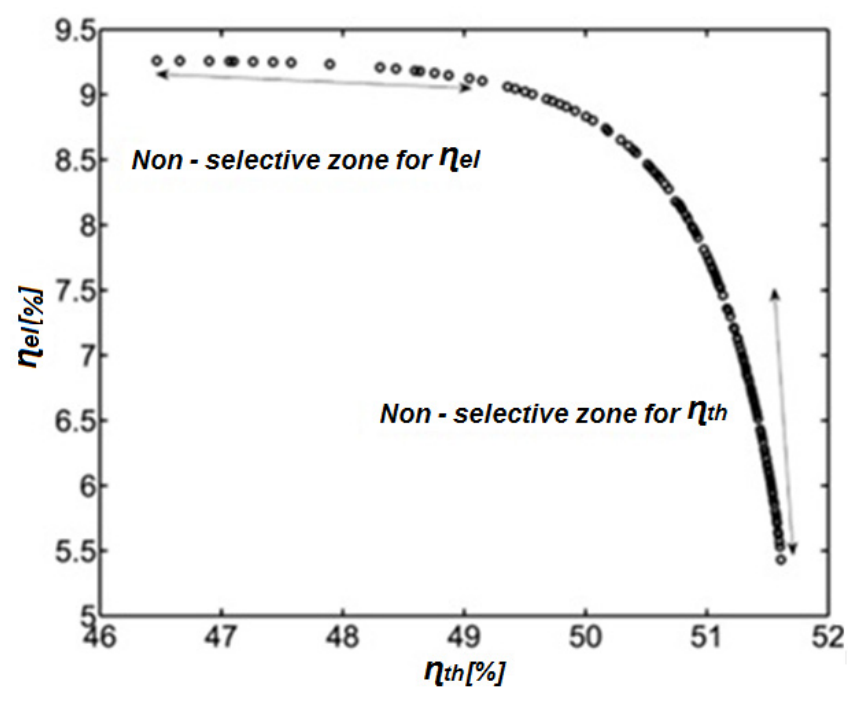

Figure 1- Optimization of thermal efficiency versus electrical efficiency of PV/T collector [3]

Two thin silicon film photovoltaic panels of type ASI ${ }^{\circledR}-\mathrm{F} 32 / 12$ for $12 \mathrm{~V}$ applications are presented in [8-10]. Cooling pipes are mounted on the back of the first solar panel converting it in $\mathrm{PV} / \mathrm{T}$ panel. The implemented experiments with both panels are described and their characteristics have been compared. The results show that the electrical efficiency of the combined PV/ T panel is increased by about 3\% compared with the standard one. Additionally - the heat output is 9 times greater than the corresponding electrical power.

The aim of the present study is to perform tests with advanced $\mathrm{PV}$ and $\mathrm{PV} / \mathrm{T}$ modules from polycrystalline silicon (pc-Si) produced by the company CRANE [5]. The experiments will be similar to the tests implemented in [10]. The solar panels have much greater electrical power $-250 \mathrm{Wp}$. The electrical parameters of both panels are identical. The construction of the PV/T panel is designed as PV module with cooling pipes added to back side at the factory [11-14]. The effect of the cooling pipes on the efficiency of the PV/ T panel, and the relationships between the heat flow rate and the produced electrical power will be investigated.

\section{Test installation} [5]:

The modules we use are of the following types

-PV solar panel of the type polycrystalline silicon (pc-Si) photovoltaic $250 \mathrm{Wp}$;

-PV/T Solar Module CPVT60P250 with rated electrical power of $250 \mathrm{Wp}$.
Suitable applications for the above mentioned solar panels are as follows [16]:

- Grid connected systems;

-Autonomous systems.

Another suitable application for the PV/T Solar Module CPVT60P250 should be the following [17]:

-Accessing to existing heating systems for homes and office buildings, heating pool water, or cooling by means of chillers.

Here is a list of the benefits for the combined $\mathrm{PV} / \mathrm{T}$ panel [17]:

-Double effect - produce electricity and heat;

-Save space 1 module for 2 systems;

- Greatly improved paybacks over the combination of traditional PV \& thermal technologies;

- Provides opportunities to most residential and light commercial low energy buildings to reach zero emission;

-Increase life of solar cells;

- Suitable for off-grid installation;

-Suitable with types off installation;

- Compact design;

- Low maintenance;

- Not necessary to enter cold water to reduce hazard of preheating of the water.

The typical uses of this module include $30.5 \mathrm{~V}$ stand-alone applications such as lighting systems, solar home systems, displays, light and guidance systems, telecommunications, driving systems (e.g. water-pump plants, gates), robots, and mobile applications (e.g. campers). Through the connection of higher system voltages, the modules are also 
excellently suited for the implementation of grid connected photovoltaic systems [18].

Some of the electrical data of both PV solar panel is shown in Table 1.

The thermal data of the Solar Module for 30.5 V-Applications CPVT60P250 is shown in Table 2.
The main components of the installation are a combined PV/T solar panel and an ordinary photovoltaic solar panel (their pictures are shown in Figure 2). Some of the measurement elements are presented there, too. Both panels are oriented to the south with a slope of $40^{\circ}$.

Table 1 - Electrical data of the PV solar panel of the type polycrystalline silicon (pc-Si) photovoltaic $250 \mathrm{Wp}$ and solar module for $30.5 \mathrm{~V}$ applications CPVT60P250 [19-20]

\begin{tabular}{lcc}
\hline \hline & Electrical data & \\
\hline \hline Parameter & units & value \\
\hline Number of cells & Wp & 60 \\
Electrical power & $\mathrm{V}$ & $250-1+3 \%$ \\
Voltage at maximum power & $\mathrm{V}$ & 30.5 \\
Open circuit voltage & $\mathrm{A}$ & 37.8 \\
Current at maximum & $\mathrm{A}$ & 8.2 \\
Short-circuit current & $\%$ & 8.75 \\
Efficiency & ${ }^{\circ} \mathrm{C}$ & 15.3 \\
Working temperature range & $\mathrm{V}$ & -40 to 85 \\
Maximal system voltage & $\mathrm{A}$ & 1000 \\
Rated diode current & & 20 \\
\hline \hline
\end{tabular}

Table 2 - Thermal data of the Solar Module for 30.5 V-Applications CPVT60P250 [5]

\begin{tabular}{lcc}
\hline \hline & Thermal data & \\
\hline \hline Parameter & units & value \\
\hline Aperture area & $\mathrm{m}^{2}$ & 1.15 \\
Thermal efficiency, $\eta_{0}$ & $\%$ & 55 \\
Nominal heat flow rate & $\mathrm{W}$ & 890 \\
Volume flow rate & $1 / \mathrm{min}$ & $1.5-2.5$ \\
Flow losses & $\mathrm{mm} \mathrm{H} \mathrm{H}_{2} \mathrm{O}$ & $540-880$ \\
Fluid volume & 1 & 1.2 \\
Effective thermal capacity & $\mathrm{kJ} / \mathrm{K}$ & 13.2 \\
\hline \hline
\end{tabular}

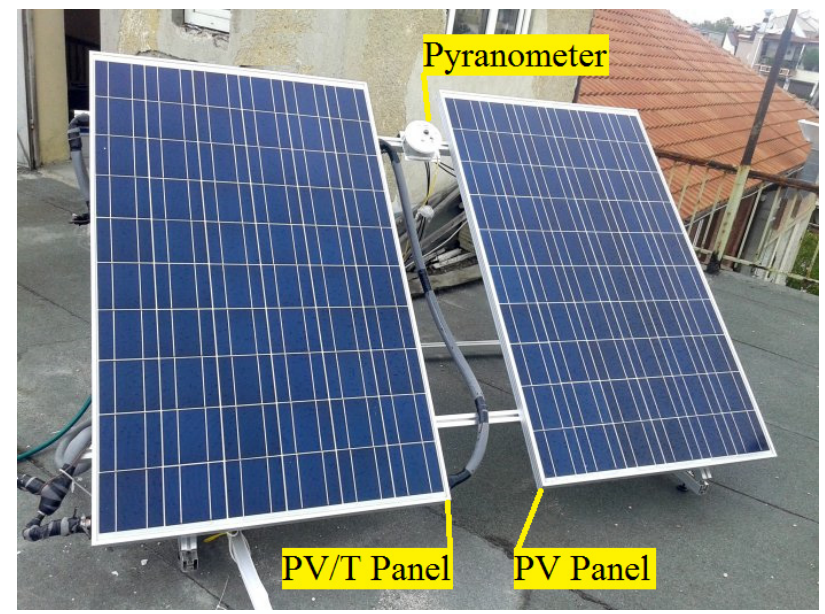

a)

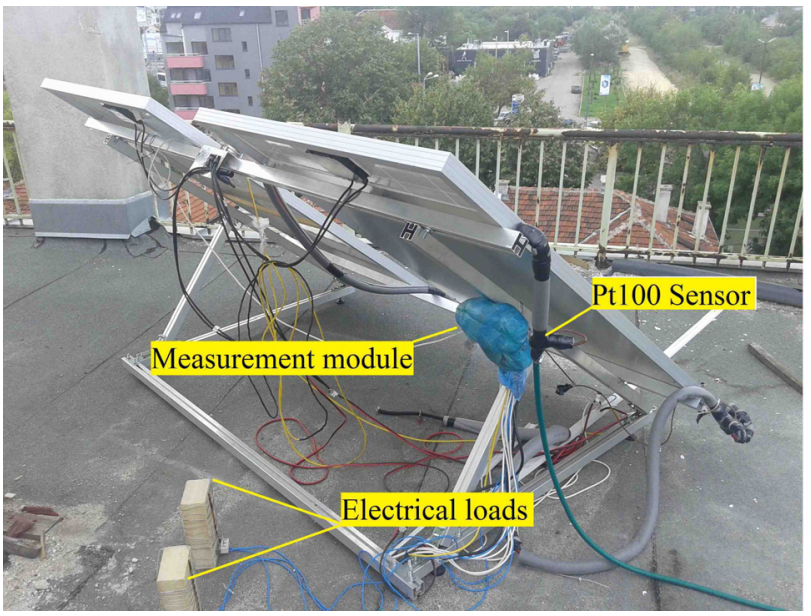

b)

Figure 2-View of PV polycrystalline silicon (pc- Si) photovoltaic $250 \mathrm{Wp}$ and PV/ T - CPVT60P250 panels: a) front view; b) back view 
A sectional view of Solar Module CPVT60P250 is presented in Figure 3.

The experimental layout is shown in Figure 4.

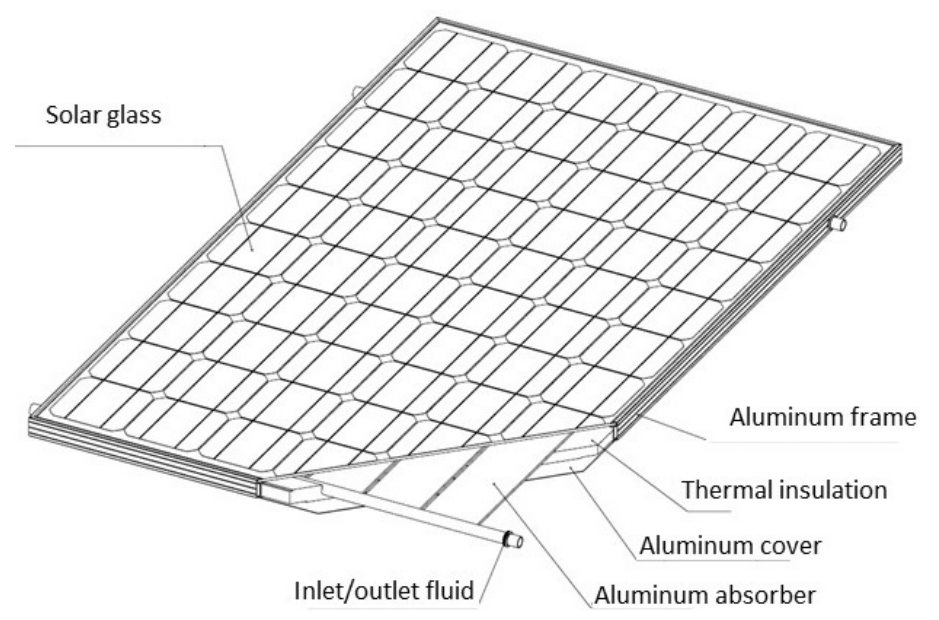

Figure 3 - Solar Module CPVT60P250 [5]

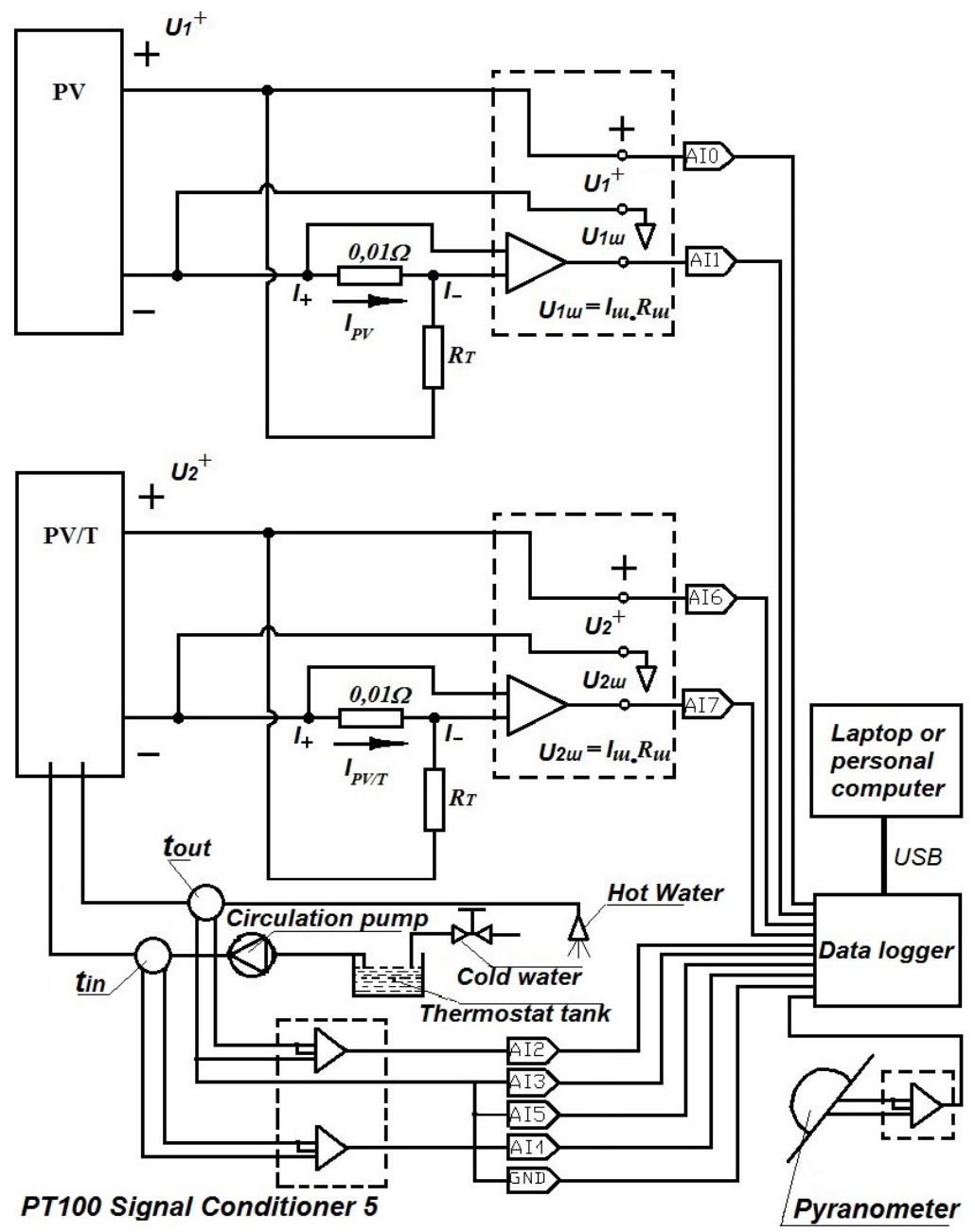

Figure 4 - Installation setup 
A circulation pump is used to transport the cooling fluid through the combined panel and the thermostatic tank (it is used to maintain a constant fluid temperature in the PV/T panel circuit). PT100 sensors and signal conditioners are used to measure the inlet and outlet fluid temperatures in pipes. The signal is sent then to a data logger and treated by means of a Laptop or personal computer. Kipp \& Zonen CMP6 pyranometer is mounted in the panel plane and is used to measure the global solar radiation.

The described installation is also used to measure the electrical power gained by both panels. For this purpose DC currents and voltages produced by the panels are measured. Two resistive loads $\left(\mathrm{R}_{\mathrm{T}}\right)$ are connected in circuit by means to dissipate a produced electrical energy. The heat flow rate is determined, too. The main goal is to compare the electrical efficiencies of the two panels. The quantity of the gained thermal energy by the $\mathrm{PV} / \mathrm{T}$ panel is calculated as well.

\section{Experimental results}

The experiment was carried out during 3 days 16, 18 and 22 of August 2016. There were done 9 tests at different mean fluid temperatures (the mean value of inlet and outlet fluid temperature), inside the range of $25-60{ }^{\circ} \mathrm{C}$. Each test had duration of about $20 \mathrm{~min}$. The following parameters were measured: intensity of the global solar irradiation by means of pyranometer, ambient temperature, fluid flow rate, inlet and outlet fluid temperature trough the $\mathrm{PV} / \mathrm{T}$ panel, produced electrical power by PV panel and produced electrical power by $\mathrm{PV} / \mathrm{T}$ panel. The produced by PV/T panel heat flow rate, the ratio of electrical power produced by $\mathrm{PV} / \mathrm{T}$ and $\mathrm{PV}$ panels, and the ratio of produced heat flow rate to electrical power by PV/T panel were calculated. All the mentioned parameters are shown in Table 3.

Table 3 - Test results

\begin{tabular}{|c|c|c|c|c|c|c|c|c|c|}
\hline$\overline{\text { Paran }}$ & Test 1 & Test 2 & Test 3 & Test 4 & Test 5 & Test 6 & Test 7 & Test 8 & Test 9 \\
\hline Date & 22.08 .16 & 16.08 .16 & 22.08 .16 & 16.08 .16 & 16.08 .16 & 22.08 .17 & 16.08 .17 & 22.08 .17 & 22.08 .17 \\
\hline Start time, $\mathrm{h}$ & $14: 43$ & $12: 45$ & $12: 13$ & 13:06 & $13: 40$ & 13:09 & $14: 25$ & $13: 43$ & $14: 19$ \\
\hline $\begin{array}{l}\text { ntensity of the global solar } \\
\text { adiation at the panel plane, } \\
\mathrm{V} / \mathrm{m}^{2}\end{array}$ & 714 & 787 & 805,5 & 793 & 754 & 779,78 & 692,46 & 748 & 763 \\
\hline Ambient air temperature, ${ }^{\circ} \mathrm{C}$ & 36,6 & 33,98 & 3,57 & 35,07 & 36,4 & 35,64 & 34,81 & 37,23 & 37,08 \\
\hline PV cell tempera & 61,1 & 65,37 & 62,1 & 63,6 & 65 & 60,6 & 59,47 & 60,5 & 59,78 \\
\hline Flow rate, $1 / \mathrm{min}$ & 2,1 & 1,55 & 2,3 & 2,3 & 2,3 & 2,3 & 2,3 & 2,3 & 2,3 \\
\hline Inlet fl & 22,97 & 26 & 31,71 & 33,63 & 37,9 & 41,6 & 44,8 & 51,06 & 60,5 \\
\hline Outlet fluid temperature, ${ }^{\circ} \mathrm{C}$ & 28,55 & 29,98 & 34,61 & 35,4 & 40,1 & 43,25 & 46,01 & 51,6 & 60,1 \\
\hline $\begin{array}{l}\text { Fluid temperature difference, } \\
{ }^{\circ} \mathrm{C}\end{array}$ & 5,68 & 3,98 & 2,9 & 1,76 & 2,28 & 1,64 & 1,02 & 0,46 & -0.36 \\
\hline Mean fluid temperature, ${ }^{\circ} \mathrm{C}$ & 25,82 & 27,99 & 33,16 & 34,52 & 39 & 42,43 & 45,41 & 51,33 & 60,03 \\
\hline Produce & 164,55 & 181,66 & 180,4 & 181,7 & 174,5 & 172,44 & 168,88 & 170,2 & 168,9 \\
\hline $\begin{array}{l}\text { ctrical power } \\
\text {, W }\end{array}$ & 166,73 & 183,36 & 182,93 & 184,48 & 175,4 & 174,5 & 167,5 & 168,73 & 164,64 \\
\hline $\begin{array}{l}\text { Produced heat flow rate (PV/ } \\
\text { T panel), W }\end{array}$ & 557 & 262,02 & 313,6 & 191,34 & 247,4 & 175,15 & 129,7 & 49,6 & $-39,7$ \\
\hline $\begin{array}{l}\text { Ratio of produced electrical } \\
\text { power by PV/T panel and } \\
\text { PV panel, \% }\end{array}$ & 101,32 & 101,49 & 101,4 & 101,53 & 100,52 & 101,19 & 99,18 & 99,14 & 97,48 \\
\hline $\begin{array}{l}\text { Ratio of produced heat flow } \\
\text { rate and electrical power by } \\
\text { PV/T panel }\end{array}$ & 3,38 & 1,59 & 1,74 & 1,05 & 1,42 & 1,02 & 0,77 & 0,29 & $-0,24$ \\
\hline
\end{tabular}


Some results from the test number 1 are presented in Figures 5 and 6 . Figure 5 shows the produced electrical power by $\mathrm{PV}$ and $\mathrm{PV} / \mathrm{T}$ panels on 22.08.17 starting at 14:43 h. Figure 6 presents the produced electrical and heat flow rate by $\mathrm{PV} / \mathrm{T}$ panel during the same test. Some fluctuations of the produced electricity may be observed in Figure 5 due to the clouds. All values presented in Table 3 are averaged inside the measurement range, which is chosen carefully for each single test in case to overcome the transition mode (the starting part of the tests - first 19 min in Figure 5) and to calculate a steady state values. The transition mode is due to the large heat capacity of the panel that has been heated prior to the start of the fluid circulation through it. It is obviously that the cooled $\mathrm{PV} / \mathrm{T}$ panel produces more electricity than the PV panel (Figure 6) in the steady state mode (selected measurement range about 2,8 min long in Figure 6). Additionally the temperature of the cooling fluid increases which leads to thermal energy production.

The ratio of produced heat flow rate and electrical power by PV/T panel summarized for all nine tests is presented in Figure 7. The ratio of produced electrical power by $\mathrm{PV} / \mathrm{T}$ and $\mathrm{PV}$ panels is presented in Figure 8 . Two trend lines have been fitted to experimental data and the equation polynomials are presented also in Figures 7 and 8 respectively.

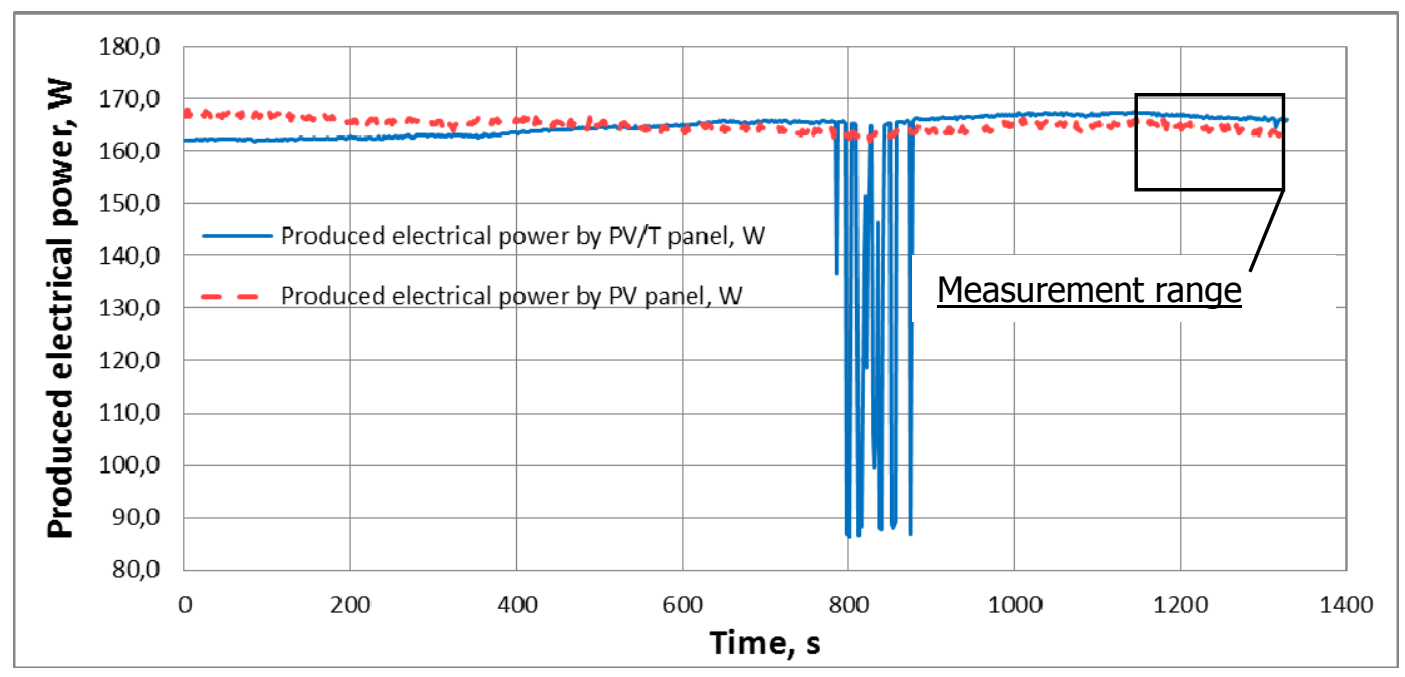

Figure 5 - Produced electrical power by PV and PV/ T panels at Test 1

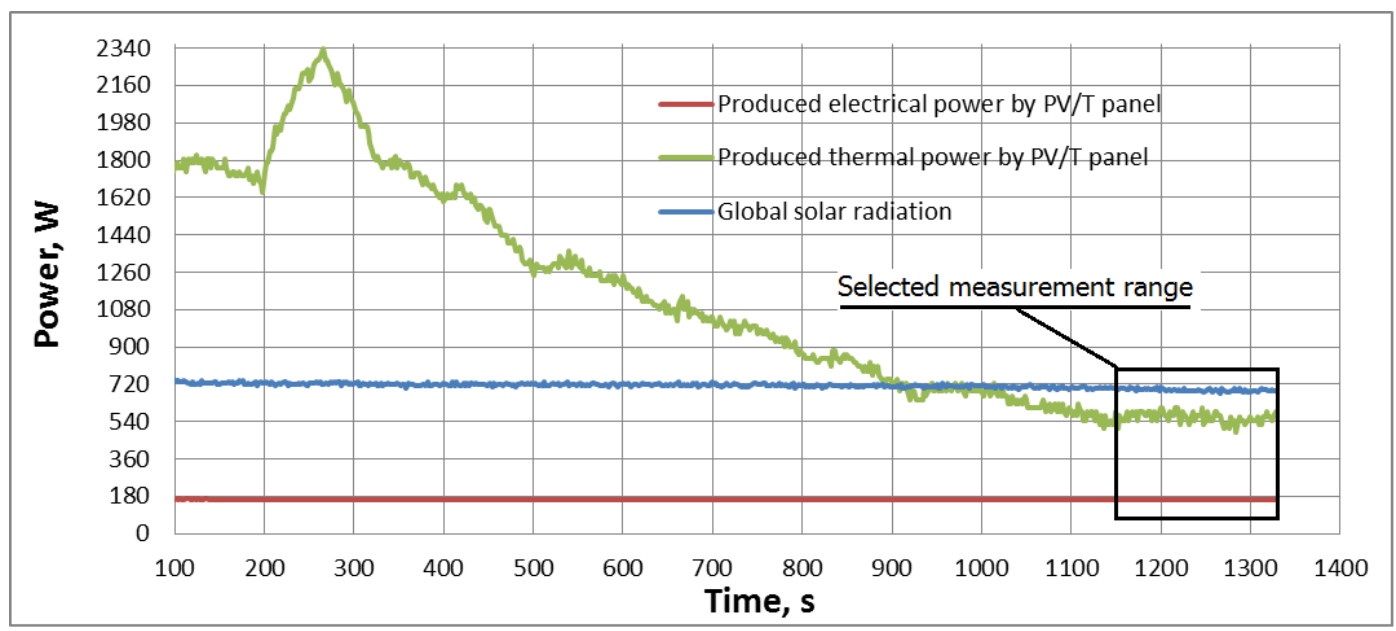

Figure 6 - Produced electrical power and heat flow rate by PV/ T panel at Test 1 


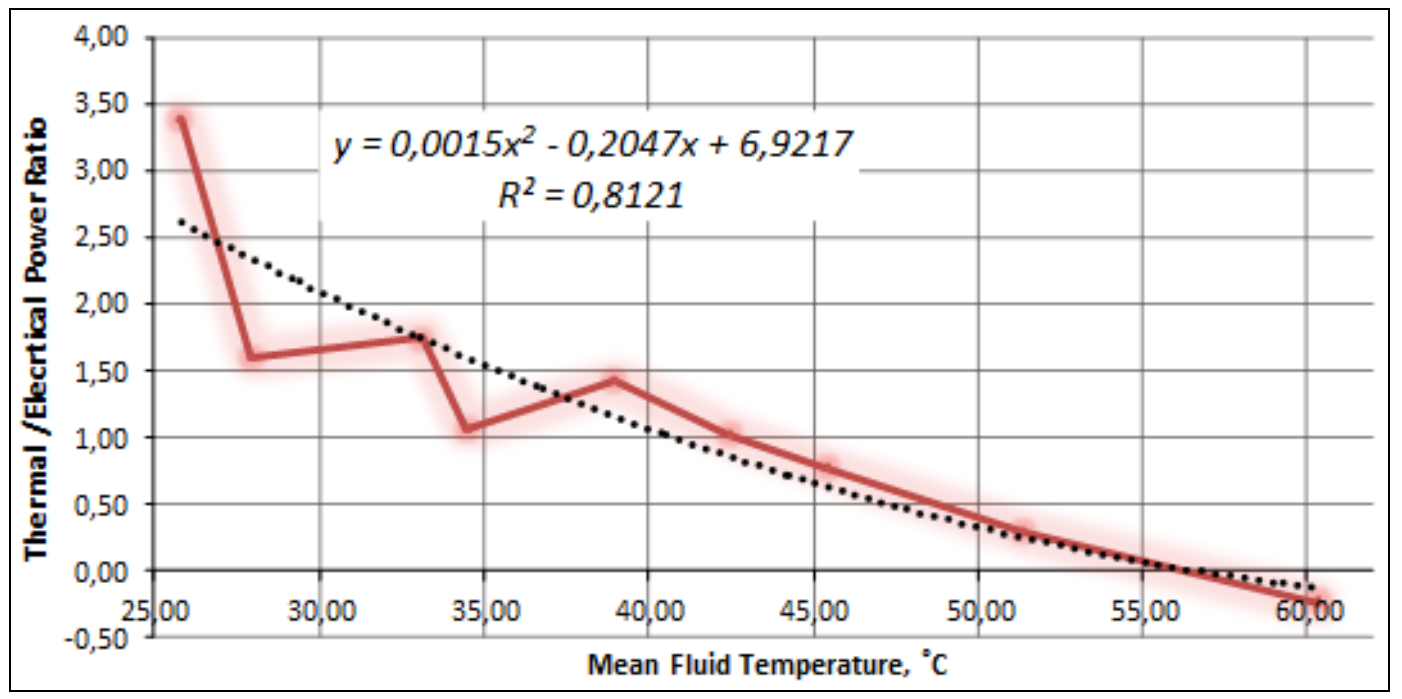

Figure 7 - Ratio of produced heat flow rate and electrical power by $\mathrm{PV} / \mathrm{T}$ panel

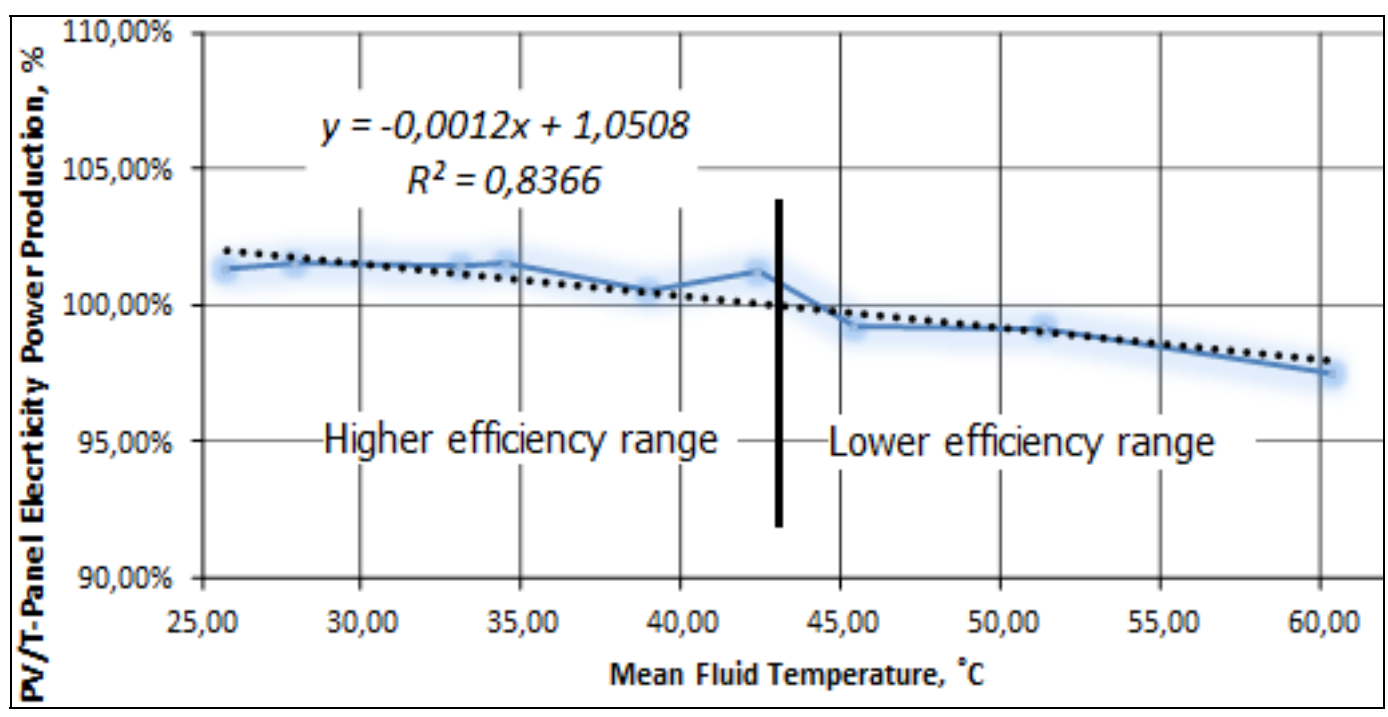

Figure 8 - Ratio of produced electrical power by PV/ T panel and PV panel vs. mean fluid temperature

\section{Conclusions}

An experimental work to measure the electrical power of two solar panels $\mathrm{PV} \mathrm{PV} / \mathrm{T}$ types is implemented. The following conclusions can be drawn on the base of the work done:

- the PV/T panel, when is more intensively cooled by means of a fluid, has higher efficiency than the other panel; this happens in the mean temperature range up to $43{ }^{\circ} \mathrm{C}$ (Figure 8 - Higher efficiency range);
- the PV panel, has higher efficiency than the $\mathrm{PV} / \mathrm{T}$ panel at the mean fluid temperatures higher than $43{ }^{\circ} \mathrm{C}$ (Figure 8 - Lower efficiency range); this is due to better PV panel cooling by the ambient air in this range;

- the electrical power produced by PV/T panel is higher by $1.5 \%$ then the electrical power produced by PV panel at the mean fluid temperatures up to $35^{\circ} \mathrm{C}$;

- the production of thermal energy is relatively high (0,29-3,38 times more than the electrical power) in the whole working temperature range (from 20 till $60^{\circ} \mathrm{C}$ ); than lower the working 
temperature of the panel is, so higher the gained heat flow rate becomes because of the higher heat transfer rate and lower heat losses (Table 2);

- a good stability of the produced electrical and thermal energy in a relatively large temperature interval is reported (Fig. 8);

- compared to the earlier silicon thin film panel experiments described in [4], we have about a 2times lower effect of efficiency gain on polycrystalline PV cells produced by CRANE using combined PV/T technology.

\section{Acknowledgements}

The author expresses the huge appreciation to Crane Ltd. Plovdiv, Bulgaria, (http://cranebg.com/en) for the experimental and theoretical supports.

\section{References}

1. M. A. Fares, L. Atik, G. Bachir, M. Aillerie, Photovoltaic panels characterization and experimental testing // Energy Procedia. -2017, - Vol. 119. -P. 945-952.

2. S. A. Kalogirou, S. Karellas, V. Badescu, K. Braimakis. Exergy analysis on solar thermal systems: A better understanding of their sustainability // Renewable Energy. -2016. Vol. 85. -P.1328-1333.

3. R. W. Moss, P. Henshall, F. Arya, G. S. F. Shire, P. C. Eames. Performance and operational effectiveness of evacuated flat plate solar collectors compared with conventional thermal, PVT and PV panels //Applied Energy. To be published in 2018. DOI: 10.1016/j.apenergy.2018.01.001.

4. A. Ramos, M. A. Chatzopoulou, I. Guarracino, J. Freeman, Ch. N. Markides. Hybrid photovoltaic-thermal solar systems for combined heating, cooling and power provision in the urban environment // Energy Conversion and Management. -2017. - Vol. 150. -P. 838-850.

5. T. Matuska. Performance and economic analysis of hybrid PVT collectors in solar DHW system // SHC 2013, International Conference on Solar Heating and Cooling for Buildings and Industry, September 23-25, 2013, Freiburg, Germany. -3013. -P. 1-3.

6. J.-H. Kim, J.-T. Kim. Comparison of electrical and thermal performances of glazed and unglazed PVT collectors // International Journal of Photoenergy. -2012. -Vol. 2012. -P. 957847- 957853

7. M. M. Adeli, F. Sobhnamayan, S. Farahat, M. A. Alavi, F. Sarhaddi. Experimental performance evaluation of a photovoltaic thermal (PV/T) air collector and its optimization // Journal of Mechanical Engineering. -2012. -Vol. 58. -P. 309-318.

8. A. F. Boudjabi, D. Abada, N. El Houda Benbghila, R. Ghoul. Experimental study of a "hybridized" photovoltaic panel // Energy Procedia. -2017. - Vol. 115. -P. 290-297.

9 T. E. Kunh. State of the art of advanced solar control devices for buildings // Solar Energy. -2017. -Vol. 154. -P. $112-133$

10. A. Georgiev, R. Popov, I. Valkov. N. Kaloferov. Utilization of the thermal energy potential in photo voltaic solar panels. World Renewable Energy Congress XI 25-30 September 2010, Abu Dhabi, UAE. -2010. -P. 1-4.

11. Zh. Yin, L. Enshen, Zh. Xinhui, J. Zhenghao, M. Yang. Combined solar heating and air-source heat pump system with energy storage: thermal performance analysis and optimization // Procedia Engineering. -2017. - Vol. 205. P. 4090-4097.

12. Ch. Maurer, Ch. Cappel, T. E. Kuhn. Progress in building-integrated solar thermal systems // Solar Energy. 2017. -Vol. 154. - P.158-186.

13 X. Yang, L. Sun, Ya. Yuan, X. Zhao, X. Cao. Experimental investigation on performance comparison of PV/TPCM system and PV/T system // Renewable Energy. To be published in 2018. DOI: 10.1016/j.renene.2017.11.094

14. S. Zafar, I. Dincer. Thermodynamic analysis of a combined PV/T-fuel cell system for power, heat, fresh water and hydrogen production // International Journal of Hydrogen Energy. -2014. - Vol. 19 (39). -P. 9962-9972.

15. F. Saeedi, F. Sarhaddi, A. Behzadmehr. Optimization of a PV/T (photovoltaic/thermal) active solar still // Energy. -2015. -Vol. 87. -P. 142-152.

16. C. Ulloa, J. M. Nuñez, A. Suárez, Ch. Lin. Design and development of a PV-T test bench based on Arduino // Energy Procedia. -2017. -Vol. 14. -P. 71-75.

17. A. Prieto, U. Knaack, T. Auer, T. Klein. Solar coolfacades: Framework for the integration of solar cooling technologies in the building envelope // Energy. -2017. -Vol. 137. - P. 353-368.

18. G. Puglisi, G. Morosinotto, G. Emmi. Development of an advanced simulation model for solar cooling plants // Energy Procedia. -2015. -Vol. 70. -P. 495-503.

19. A. M. Abdel Dayem, M. Nabil Metwally, A. S. Alghamdi, E. M. Marzouk. Numerical simulation and experimental validation of integrated solar combined power plan // Energy Procedia. -2014. - Vol. 50. -P. 290-305.

20. M. Ambrose, M. James. Dealing with energy efficiency data // Energy Procedia. - 2017. -Vol. 121. -P. 158-165. 